\title{
PERANAN QHSSE MANAGEMENT DALAM UPAYA MENINGKATKAN KEAMANAN DAN KESELAMATAN KERJA PADA PT. JASA ARMADA INDONESIA JAKARTA
}

\author{
Retno Indriyati $1^{1 *}$, Nurlia Laila Sofa ${ }^{2}$ \\ ${ }^{1}$ Program Studi Nautika, Politeknik Bumi Akpelni \\ Jln. Pawiyatan Luhur II/17 Bendan Dhuwur Semarang \\ ${ }^{2}$ Program Studi KPN, Politeknik Bumi Akpelni \\ Jln. Pawiyatan Luhur II/17 Bendan Dhuwur Semarang \\ *Email:retno@akpelni.ac.id
}

\begin{abstract}
Abstrak
Keselamatan kerja diartikan sebagai suatu pemikiran dan upaya untuk menjamin keutuhan dan kesempurnaan baik jasmaniah maupun rohaniah tenaga kerja pada khususnya dan manusia pada umumnya serta hasil budaya dan karyanya, sebagai suatu pengetahuan dan penerapannya dalam usaha mencegah kemungkinan terjadinya kecelakaan dan penyakit akibat kerja. Penelitian ini merupakan penelitian deskriptif yang bertujuan untuk menganalisis peranan QHSSE Management dalam upaya meningkatkan keamanan dan keselamatan kerja pada PT. Jasa Armada Indonesia Jakarta. Hasil pembahasan membuktikan bahwa Kesadaran Awak Kapal Terhadap Penggunaan Alat Pelindung Diri (APD) Masih Kurang, Awak Kapal Belum Menerapkan Implementasi ISM Code diatas Kapal sesuai dengan Harapan QHSSE Management dan Perawatan Kapal Belum Optimal. Keselamatan dan keamanan kerja merupakan prioritas utama bagi seorang pelaut saat bekerja diatas kapal. Oleh karena itu, penggunaan alat pelindung diri sangat penting bagi awak kapal pada saat bekerja di atas kapal. Perusahaan harus memberikan tanggung jawab terhadap semua orang yang hidup atau bekerja diatas kapal untuk mengimplementasikan ISM-Code dengan baik, dan selain itu perawatan kapal merupakan hal penting yang harus di perhatikan dari sebuah kapal, sehingga harus dilakukan secara rutin.
\end{abstract}

Kata kunci : Awak Kapal, Keamanan dan Keselamatan Kerja, dan QHSSE

\section{PENDAHULUAN}

Menurut Endang, dalam https://prodiaohi.co.id/kesehatan-dankeselamatan-kerja Kesehatan dan Keselamatan Kerja (K3) merupakan salah satu upaya untuk menciptakan tempat kerja yang aman, sehat, bebas dari pencemaran lingkungan, sehingga dapat mengurangi dan atau bebas dari kecelakaan kerja dan penyakit akibat kerja yang pada akhirnya dapat meningkatkan efisiensi dan produktivitas kerja.

Keselamatan kerja secara filosofi diartikan sebagai suatu pemikiran dan upaya untuk menjamin keutuhan dan kesempurnaan baik jasmaniah maupun rohaniah tenaga kerja pada khususnya dan manusia pada umumnya serta hasil budaya dan karyanya. Dari segi keilmuan diartikan sebagai suatu pengetahuan dan penerapannya dalam usaha mencegah kemungkinan terjadinya kecelakaan dan penyakit akibat kerja. Menurut UndangUndang Pokok Kesehatan RI No. 9 Tahun 1960, BAB I pasal 2, Kesehatan kerja adalah suatu kondisi kesehatan yang bertujuan agar masyarakat pekerja memperoleh derajat kesehatan setinggitingginya, baik jasmani, rohani, maupun sosial, dengan usaha pencegahan dan pengobatan terhadap penyakit atau gangguan kesehatan yang disebabkan oleh pekerjaan dan lingkungan kerja maupun penyakit umum.

OHSAS18001:2007 mendefinisikan Keselamatan dan Kesehatan Kerja sebagai kondisi dan faktor yang mempengaruhi atau akan mempengaruhi keselamatan dan kesehatan pekerja (termasuk pekerja kontrak dan kontraktor), tamu atau orang lain di tempat kerja.

Kecelakaan kerja tidak saja menimbulkan korban jiwa maupun kerugian materi bagi pekerja dan 
pengusaha, tetapi juga dapat mengganggu proses produksi secara menyeluruh, merusak lingkungan yang pada akhirnya akan berdampak pada masyarakat luas. Keselamatan dan Kesehatan Kerja merupakan satu upaya pelindungan yang diajukan kepada semua potensi yang dapat menimbulkan bahaya. Hal tersebut bertujuan agar tenaga kerja dan orang lain yang ada di tempat kerja selalu dalam keadaan selamat dan sehat serta semua sumber produksi dapat digunakan secara aman dan efisien (Suma'mur, 2006). Undang-Undang Nomor 23 Tahun 1992 tentang Kesehatan mengamanatkan antara lain, setiap tempat kerja harus melaksanakan upaya kesehatan kerja, agar tidak terjadi gangguan kesehatan pada pekerja, keluarga, masyarakat dan lingkungan disekitarnya.

Penerapan Sistem Manajemen

Keselamatan dan Kesehatan Kerja yang terintegrasi berperan dalam menurunkan angka kejadian kecelakaan kerja dan penyakit akibat kerja. Penyakit akibat kerja Menurut H. W. Heinrich dalam Notoatmodjo (2007), penyebab kecelakaan kerja yang sering ditemui adalah perilaku yang tidak aman sebesar $88 \%$, kondisi lingkungan yang tidak aman sebesar $10 \%$, atau kedua hal tersebut di atas terjadi secara bersamaan.

PT. Jasa Armada Indonesia, merupakan perusahan pelayaran yang bergerak di bidang pemanduan dan Penundaan kapal angkutan laut dan layanan maritim, yang berkomitmen penuh untuk melaksanakan standar tinggi di bidang kesehatan, keselamatan, lingkungan, kualitas dan keamanan. Komitmen terhadap nilai-nilai korporasi adalah landasan dari seluruh layanannya, yang dimulai dari puncak pimpinan hingga keseluruh tingkat dibawahnya. Selain itu PT. Jasa Armada Indonesia juga berpedoman menjaga keselamatan kapal pada saat akan sandar dipelabuhan. Seiring dengan Visi dan Misi perusahaan untuk selalu melaksanakan kegiatan operasional yang aman dan selalu memperhatikan Keselamatan, Keamanan,
Kesehatan Kerja dan Perlindungan Lingkungan, maka PT. Jasa Armada Indonesia mengimplementasikan Sistem Manajemen yang terpadu/terintegrasi berdasarkan Sistem Manajemen Mutu ISO 9001:2015, Sistem Manajemen Lingkungan ISO 14001:2015, dan Sistem Manajemen Keselamatan dan Kesehatan Kerja ISO 45001:2018 yang dinamakan Sistem Manajemen Quality, Health, Safety, Security and Environment (QHSSE). Sebagai jaminan keamanan dan keselamatan kapal pandu dan tunda yang berada di pelabuhan, dan tidak bisa dipungkiri bahwa resiko terjadinya kecelakaan pada saat pemanduan dan penundaan sangat tinggi mulai dari pergerakan kapal hingga keselamatan awak kapal, banyak faktor yang akan menjadi kendala kelancaran kegiatan pemanduan dan penundaan, baik faktor alam maupun faktor lokasi.

Sumber daya manusia sangat berperan penting terhadap perkembangan perusahaan apalagi melihat resiko yang tinggi pada saat pemanduan dan penundaan kapal, tentu harus sangat diperhatikan keamanan dan keselamatan kapal serta awak apalagi dengan padatnya kapal yang ada di pelabuhan dan keterbatasan sarana maka pemanduan dan penundaan sangat berperan penting untuk kelancaran kapal sandar dan kapal keluar dari pelabuhan. Di Pelabuhan Tanjung Priok sendiri pergerakan kapal keluar masuk pelabuhan sangat padat yang mengharuskan kapal besar atau kapal muatan khusus membutuhkan pemanduan dan penundaan yang tentu akan menghadapi beberapa resiko dan bahaya baik terhadap kapal mapuan awak kapal.

Untuk meningkatkan dan menerapkan keamanan serta keselamatan kapal dan awak kapal pada PT. Jasa Armada Indonesia Tbk, peranan QHSSE Management sangat penting untuk mengantisipasi bahaya dan resiko kecelakaan di atas kapal. Berdasarkan hal tersebut, maka perumusan masalah dalam penelitian ini adalah mengkaji bagaimana 
Kesadaran awak kapal dalam penggunaan Alat Pelindung Diri (APD), Implementasi ISM Code diatas Kapal dan bagaimana perawatan kapal untuk mewujudkan keamanan dan keselamatan kerja dilakukan sehingga menciptakan suasana kerja yang nyaman.

\section{LANDASAN TEORI QHSSE}

QHSSE adalah Quality, Health, Safety Security, and Environment

Sistem Manajemen Terpadu PT. JAI (yang disingkat menjadi SM- QHSSE PT. JAI yang meliputi Sistem Manajemen Mutu ISO 9001:2015, Sistem Manajemen Lingkungan ISO 14001:2015, dan Sistem Manajemen Keselamatan dan Kesehatan Kerja ISO 45001:2018 serta sistem manajemen keamanan yang digunakan untuk mengembangkan dan menerapkan mutu, keselamatan, keamanan dan kesehatan kerja, dan lingkungan Perusahaan, dengan mengelola aspek mutu dan lingkungan, serta risiko Kesehatan, Keselamatan, dan Keamanan Perusahaan, yang mencakup persyaratan SM-QHSSE.

Sistem Manajemen QHSSE PT. Jasa Armada Indonesia Tbk yang meliputi Sistem Manajemen Mutu ISO 9001:2015, Sistem Manajemen Lingkungan ISO 14001:2015, dan Sistem Manajemen Keselamatan dan Kesehatan Kerja ISO 45001:2018 serta sistem manajemen keamanan diterapkan agar:

a. Proses bisnis yang ada dalam lingkup kegiatan PT. Jasa Armada Indonesia Tbk dapat dikelola dengan baik dan dapat ditingkatkan sesuai dengan arah kebijakan perusahaan dan stakeholder

b. Diperoleh efisiensi dan efektifitas kerja dalam segala hal termasuk waktu dan biaya dengan penerapan sistem manajemen yang efektif, fokus, dan terpadu dalam mengendalikan kegiatan internal termasuk risikorisikonya.

c. Meningkatkan manajemen, komunikasi

serta wawasan,

pengetahuan, dan ketrampilan seluruh pekerja.

d. Meningkatkan kepercayaan dan kepuasan pemangku kepentingan (stakeholder) melalui penerapan proaktif International Management System dengan baik.

e. Membangun citra positif terhadap reputasi perusahaan serta meningkatkan motivasi dan kebanggaan seluruh pekerja.

f. Menstandarkan sistem manajemen keselamatan dengan port authority keamanan setempat.

\section{Keamanan dan Keselamatan Kerja}

Menurut Hamdani dan Haikal (2012) Kesehatan, keselamatan dan keamanan kerja ( K3 ) adalah suatu upaya guna memperkembangkan kerja sama, saling pengertian, dan saling partisipasi efektif dari pengusaha atau pengurus dan tenaga kerja dalam tempat-tempat kerja untuk melaksanakan tugas dan kewajiban bersama dibidang keselamatan, kesehatan, dan keamanan kerja, dalam rangka melancarkan usaha produksi. Melalui pelaksanaan K3 diharapkan tercipta tempat kerja yang aman, sehat, bebas dari pencemaran lingkungan, sehingga dapat mengurangi atau terbebas dari kecelakaan dan penyakit akibat kerja.

$$
\text { Soehatman Ramli }
$$

Keselamatan adalah kebutuhan setiap manusia dan menjadi naluri dari setiap makhluk hidup. Sejak manusia bermukim di muka bumi, secara tidak sadar mereka telah mengenal aspek keselamatan untuk mengantisipasi berbagai bahaya disekitar lingkungan hidupnya.

Menurut Butanto

Keselamatan kerja adalah suatu keadaan terhindar dari bahaya selama melakukan pekerjaan. Keselamatan kerja adalah salah satu faktor yang harus dilakukan selama kerja.

Menurut Suma'mur (2009) Keselamatan kerja dalam UU No.1 Tahun 1970 adalah keselamatan kerja segala tempat kerja, baik didarat, didalam 
tanah, dipermukaan air, di dalam air maupun di udara, yang berada didalam wilayah kekuasaan hukum Republik Indonesia.

Sajidi Hadipoetro (2014 ) sistem manajemen keselamatan dan kesehatan kerja (SMK3) adalah bagian dari sistem manajemen secara keseluruhan yang meliputi struktur organisasi, perencanaan, tanggung jawab, pelaksanaan, perosedur, proses dan sumber daya yng dibutuhkan bagi pengembangan, penerapan, pencapaian, pengkajian, dan pemeliharaan kebijakan K-3, kegiatan SMK 3 dilaksanakan dalam rangka pengendalian risiko yang berkaitan dengan kegiatan kerja guna tercapainya tempat kerja yang aman, efisien, dan produktifitas tinggi.

\section{Awak Kapal}

Menurut UU No.17 Tahun 2008 tentang pelayaran, awak kapal adalah orang yang bekerja atau dipekerjakan di atas kapal oleh pemilik atau operator kapal untuk melaksanakan tugas di atas kapal sesuai dengan jabatan yang tercantum dalam buku sijil.

Dalam PP.RI No.7 Tahun 2000 tentang kepelautan, awak kapal adalah orang yang bekerja atau dipekerjakan di atas kapal oleh pemilik atau operator kapal untuk melakukan tugas di atas kapal sesuai dengan jabatannya yang tercantum dalam buku sijil.

Menurut PP. RI No.51 Tahun 2002 tentang perkapalan, awak kapal adalah orang yang bekerja atau yang dipekerjakan diatas kapal oleh pemilik atau operator kapal untuk melakukan tugas di atas kapal sesuai dengan jabatannya yang tercantum dalam buku sijil.

Adapun hak dan kewajiban awak kapal adalah sebagai berikut:

1. Hak-Hak Awak Kapal

a. Hak atas upah

b. Jam kerja dan jam istirahat

c. Hak atas permakanan dan penginapan dikapal d. Hak atas cuti

d. Hak atas perawatan kalau sakit dikapal e. Hak atas angkutan bebas ketempat tujuan dan tempat asal

f. Kompensasi apabila kapal tidak dapat beroperasi karena mendapat kecelakaan

g. Kesempatan mengembangkan karier

2. Kewajiban Awak Kapal

a. Mentaati perintah perusahaan

b. Bekerj sesuai jangka waktu perjanjian

c. Melaksanakan tugas sesuai jam kerja yang ditetapkan

d. Hak perusahaan adalah memperkerjakan pelaut sesuai dengan perjanjian.

Adapun permasalahan yang terjadi pada PT. Jasa Armada Indonesia yang terkait dengan keselamtan kerja adalah sebagai berikut :

1. Kesadaran awak kapal terhadap penggunaan Alat Pelindung Diri (APD) masih kurang.

2. Awak Kapal Belum Menerapkan Implementasi ISM Code diatas Kapal sesuai Harapan QHSSE Management.

3. Perawatan kapal yang belum optimal.

\section{METODE}

Penelitian adalah proses karya ilmiah yang mencakup sifat formal dan intensif. Karakter formal dan intensif karena mereka tidak dengan aturan, urutan, maupun cara penyajian agar memperoleh hasil yang di akui dan bermanfaat bagi kehidupan manusia. Intensif dengan menerapkan ketelitian dan ketepatan dalam melakukan proses penelitian agar memperoleh hasil yang dapat ditanggung jawabkan, memecahkan problem melalui hubungan sebab dan akibat, dapat diulang kembali dengan cara yang sama dan hasil sama. Adapun pengumpulan data yang dilakukan oleh penulis adalah dengan cara observasi yaitu pengamatan langsung pada obyek yang diteliti, dalam hal ini peneliti melakukan pengamatan pada PT. Jasa Armada Indonesia Tbk. Selain itu, peneliti menggunakan metode wawancara yaitu metode dengan cara tanya jawab langsung dengan sumber yang terkait dengan permasalahan yang dibahas. Wawancara dilakukan dengan pegawai PT. Jasa 
Armada Indonesia Tbk dan awak kapal yang ditemui pada saat penulis mengadakan pengamatan.

\section{HASIL DAN PEMBAHASAN \\ Kesadaran Awak Kapal Terhadap Penggunaan Alat Pelindung Diri (APD) Masih Kurang.}

Alat Pelindung Diri (APD) adalah suatu alat yang mempunyai kemampuan untuk melindungi seseorang serta kelengkapan yang wajib digunakan saat bekerja sesuai bahaya dan resiko kerja. Alat pelindung diri merupakan salah satu perlengkapan keselamatan dan keamanan kerja yang tergolong penting dalam mengurangi resiko kecelakaan.

Pekerjaan diatas kapal merupakan salah satu pekerjaan yang sangat rentan terhadap bahaya kecelakaan. Keselamatan dan keamanan kerja merupakan prioritas utama bagi seorang pelaut saat bekerja diatas kapal, semua perusahaan pelayaran tentu sudah menyiapkan dan mengantisipasi adanya kecelakaan ataupun resiko kerja yang akan terjadi. Salah satunya dengan menyediakan alat pelindung diri yang diharapkan dapat mengurangi terjadinya kecelakaan terhadap awak kapal di atas kapal. Akan tetapi hal tersebut tidak bisa terlaksana tanpa adanya partisipasi dari para pekerja Hal tersebut juga bisa disebabkan karena kurangnya pemahaman terhadap pentingnya Alat Pelindung Diri. Jika ditemukan awak kapal yang tidak menggunakan Alat Pelindung Diri maka yang dilakukan oleh manajemen QHSSE adalah sebagai berikut:

a. QHSSE melakukan investigasi dengan Nakhoda dan crew diatas kapal.

b. QHSSE memberikan sosialisasi / briefing tentang pentingnya menggunakan APD jika saat melakukan pekerjaan diatas kapal.

c. QHSSE merekomendasikan kepada Crewing Department untuk memberikan surat teguran disertai dengan kompensasi pemotongan Insentive sesuai dengan peraturan yang berlaku. d. QHSSE Department membuat sosialisasi kepada seluruh Nakhoda khususnya di Armada Tanjung Priok tentang kejadian tersebut sebagai lesson learn agar tidak terulang lagi.

e. QHSSE memberikan surat teguran kepada crew kapal yang tidak menggunakan APD disertai dengan pemotongan Insentive kapal untuk seluruh crew kapal yang ada di atas kapal tersebut.

Dengan adanya teguran dan sanksi tersebut diharapkan awak kapal lebih taat dalam menggunakan Alat Pelindung Diri ( APD ) yang sudah di sediakan oleh perusahaan.

\section{Awak Kapal Belum Menerapkan Implementasi ISM Code diatas Kapal sesuai Harapan QHSSE Management.}

ISM Code merupakan produk dari IMO yang diadopsioleh SOLAS pada tahun 1994. ISM Code merupakan standar sistem Manajemen Keselamatan untuk pengoperasian kapal secara aman dan untuk pencegahan pencemaran di laut. ISM Code ini bertujuan untuk menjamin keselamatan di laut, mencegah kecelakaan atau kematian, dan juga mencegah kerusakan pada lingkungan dan kapal ISM-Code membentuk suatu standar international untuk manajemen dan operasi kapal yang aman dengan menetapkan aturan bagi perusahaan pelayaran sehubungan dengan keselamatan dan pencegahan polusi serta untuk penerapan Safety Management System (SMS). Untuk itu diperlukan adanya dukungan dari perusahaan atas kebutuhan operasional kapal yang aman, perlindungan terhadap lingkungan, dan manajemen perusahaan yang baik dengan mengoptimalkan implementasi ISM Code.Sistem Manajemen Keselamatan dibuat dalam rangka pemenuhan terhadap persyaratan IMO dan Pemerintah Republik Indonesi melalui Direktorat Jendral Perhubungan Laut tentang Sistem Manajemen Keselamatan Kapal dan Perlindungan Lingkungan (ISM-Code). Sistem Manajemen Keselamatan ini 
diterapkan pada semua kegiatan yang berkaitan dengan pengoperasian kapal, termasuk pengoperasian kapal secara aman dan perlindungan terhadap pencemaran. Selain perusahan,awak kapal juga berperan penting dalam implementasi ISM Code. Akan tetapi pada kenyatannya di PT. Jasa Armada Indonesia masih ditemukan awak kapal (ABK) kurang begitu peduli terhadap pentingya ISM-Code yang diterapkan di atas kapal, banyak awak kapal yang belum paham tentang ISM-Code, dan ketaatan awak kapal dalam menjalankan implementasi ISM-Code di atas kapal masih belum optimal, mulai dari penggunaan alat pelindung diri, perawatan kapal, dan pengisian list control keselamatan kapal belum sesuai harapan manajemen QHSSE.

Untuk meningkatkan pengetahuan dan ketaatan awak kapal terhadap ISM-Code pihak manajement QHSSE memberikan pelatihan kepada Nakhoda dan seluruh awak kapal (ABK) harus mempelajari Pedoman Manajemen Keselamatan dan prosedur-prosedur terkait untuk masingmasing kapal, segera setelah mereka bergabung dengan kapal tersebut. Sebagai bukti bahwa sistem manajemen keselamatan ini sudah dipelajari, maka Nakhoda dan seluruh ABK diwajibkan untuk mencatumkan nama, posisi, tanggal, dan tanda tangannya setelah membaca pedoman ini pada form "Lembar Pemahaman". Selain itu manajemen juga memberikan form penerapan ISM Code di setiap kapal yang wajib diisi oleh Nakhoda dan awak kapal, sehingga manajemen QHSSE dapat mengontrol implementasi ISM Code dari hasil form yang sudah diisi oleh Nakhoda dan Awak Kapal.

\section{Perawatan Kapal Belum Optimal}

Perawatan kapal merupakan hal penting yang harus di perhatikan dari sebuah kapal, perbaikan mesin yang perlu dilaksanakan terhadap seluruh obyek baik teknis, meliputi seluruh material atau benda yang bergerak atau tidak bergerak sehingga material tersebut dapat dipakai dan berfungsi dengan baik serta selalu memenuhi persyaratan Standar Internasional dan non teknis. Pengoperasian kapal yang optimal perlu didukung dengan adanya perawatan kapal yang teratur dan rutin, untuk menjaga agar kapal selalu berada dalam kondisi baik laik laut dan dapat dioperasikan untuk pengangkutan laut pada setiap saat degan kemampuan diatas kondisi minimum tertentu. Kapal merupakan aset utama yang dimiliki oleh pt jasa armada indonesia dalam bisnis yang sedang berjalan saat ini. laik laut dan dapat dioperasikan untuk pengangkutan laut pada setiap saat degan kemampuan diatas kondisi minimum tertentu. Jumlah kapal yang banyak membuat PT. Jasa Armada Indonesia belum bisa mengoptimalkan perawatan kapal, kerusakan kapal yang tak terjadi kepada salah satu kapal menghambat kapal lain yang seharusnya melakukan perawatan, sehingga kapal yang cenderung tidak rusak parah perawatannya ditunda.Keterlambatan penyediaan sparepart juga menjadi salah satu faktor yang menghambat perawatan kapal di PT. Jasa Armada Indonesia. Untuk mengatasi hal tersebut, PT. Jasa Armada Indonesia memberikan jadwal perawatan kapal secara berkala yang sudah ditetapkan, melaksanakan jadwal perawatan mingguan, bulanan dan tahunan sesuai yang sudah dijadwalkan oleh kapal. Menambah personil agar dapat mempercepat perawatan kapal. Tehnikal Superintenden tiap cabang harus menyiapkan Perencanaan Perawatan Kapal sesuai dengan prosedur, dengan memperhitungkan usia kapal, catatan perawatan, kerusakan/laporan kegagalan, dan survey-survey sesuai Peraturan Klasifikasi dan Konvensi Internasional serta mempersiapkan Perencanaan Perawatan Kapal, yang disesuaikan dengan kondisi setiap kapal. Hal ini karena instalasi dan perlengkapan masing-masing kapal berbeda satu sama lain. 
KESIMPULAN

1. Kesadaran

Terhadap

Awak

Penggunaan

Kapal

Pelindung Diri (ADP) Masih Kurang.

Jika terdapat awak kapal yang tidak menggunakan alat pelindung diri maka yang dilakukan oleh manajemen QHSSE adalah sebagai berikut:

a. QHSSE melakukan investigasi dengan Nakhoda dan crew diatas kapal.

b. QHSSE memberikan sosialisasi/ brefing tentang pentingnya menggunakan APD jika saat melakukan pekerjaan diatas kapal.

c. QHSSE merekomendasikan kepada Crewing Department untuk memberikan surat teguran disertai dengan kompensasi pemotongan Insentive sesuai dengan peraturan yang berlaku.

d. QHSSE Departement membuat sosialisasi kepada seluruh Nakhoda khususnya di Armada Tanjung Priok tentang kejadian tersebut sebagai lesson learn agar tidak terulang lagi.

e. QHSSE memberikan surat teguran kepada crew kapal yang tidak menggunakan APD disertai dengan pemotongan Insentive kapal untuk seluruh crew kapal yang ada di atas kapal tersebut.

2. Awak Kapal Belum Menerapkan Implementasi ISM Code diatas Kapal sesuai Harapan QHSSE Management.

Untuk meningkatkan pengetahuan dan ketaatan awak kapal terhadap ISM-Code pihak manajemen HSSE memberikan pelatihan kepada seluruh awak kapal (ABK) untuk mempelajari Pedoman Manajemen Keselamatan dan prosedurprosedur terkait untuk masing- masing kapal, segera setelah mereka bergabung dengan kapal tersebut. Sebagai bukti bahwa sistem manajemen keselamatan ini sudah dipelajari, maka Nakhoda dan seluruh ABK diwajibkan untuk mencatumkan nama, posisi, tanggal, dan tanda tangannya setelah membaca pedoman ini pada form "Lembar Pemahaman". Selain itu manajemen juga memberikan form penerapan ISM Code di setiap kapal yang wajib diisi oleh nakhoda dan awak kapal, sehingga manajemen HSSE dapat mengontrol implementasi ISM Code dari hasil form yang sudah diisi oleh Nakhoda dan awak kapal.

\section{Perawatan Kapal Belum Optimal.}

Memberikan jadwal perawatan kapal secara berkala yang sudah ditetapkan, melaksanakan jadwal perawatan mingguan, bulanan dan tahunan sesuai yang sudah dijadwalkan oleh kapal. Menambah personil CWS agar dapat mempercepat perawatan kapal. Tehnikal superintenden tiap Cabang harus menyiapkan Perencanaan Perawatan Kapal sesuai dengan prosedur, dengan memperhitungkan usia kapal, catatan perawatan, kerusakan/laporan kegagalan, dan survey-survey sesuai Peraturan Klasifikasi dan Konvensi Internasional serta mempersiapkan Perencanaan Perawatan Kapal, yang disesuaikan dengan kondisi setiap kapal. Hal ini karena instalasi dan perlengkapan masing-masing kapal berbeda satu sama lain.

\section{DAFTARPUSTAKA}

A. F. Stoner, James. 1996. Membuka Cakrawala Ekonomi. PT Setia Purna Invers.

Berry, david. 2003. Pengantar Sosiologi dan Perubahan Sosial. Jakarta : Bina Cipta Berry

Butanto. 2015. Panduan Praktis Keselamatan \& Kesehatan Kerja Untuk Industri. Yogyakarta : PT. Pustaka Baru. Fakhrurrozi. 2017. Penanganan, Pengaturan dan Pengamanan Muatan Kapal. Yogyakarta: Budi Utomo.

Ginanto, Herry. 2000. Pengoprasian Pelabuhan Laut. Jakarta : Sinar Sejahtera. 
Hadipoetro, Sajidi. 2014. Manajemen Komprensif Keselamatan Kerja : Jakarta. Yayasan Patra Tarbiyyah Nusantara.

Hamdani dan Haikal. 2012. Seluk Beluk Perdagangan Ekspor Impor Jilid 1 (Satu). Jakarta : Bushindo

Idris, Noch. 2000. Diklat Shipping dan Kepelabuhanan. Jakarta : Yayasan Artha Bhakti.

J Cohen, Bruce. 1990. Sosiologi Perubahan Sosial. Jakarta : Rineka Cipta. PP No.69 Tahun 2001 Tentang Kepelabuhan.

Ramli, Soehatman. 2011. Pedoman Praktis Managemen Resiko dalam Prespektif K3 OHS Risk Managemen, Edisi Kedua, PT. Dian Rakyat Jakarta.

Santoso, Budi Herman. 2012. Manajemen Pelabuhan dan Realisasi Ekspor Impor.
Yogyakarta: Andi Offset.

Suma'mur P.K. 2009. Higiene Perusahaan

Dan Keselamatan Kerja

(HIPERKES).Jakarta : CV Sagung Seto.

Sumardi. 2000. Refrensi kepelabuhanan. jakarta.

Suyono. 2003. Shipping Pengankutan Intermodal Expor Impor Melalui Laut.Jakarta: PPM.

Widiyati dan Ridwan. 2014. Kamus Kepelabuhan dan Pelayaran.

Yogyakarta : Leutikaprio

UU No.17 Tahun 2008 tentang Pelayaran.

PP. RI No.51 Tahun 2002 tentang perkapalan.

PP.RI No.7 Tahun 2000 tentang kepelautan. https://prodiaohi.co.id//kesehatan-dankeselamatan-kerja 